\title{
Establishment of an efficient callus induction and plant regeneration system in Pakistani wheat (Triticum aestivum) cultivars
}

\author{
Umer Rashid \\ Deparment of Microbiology/Biotechnology \\ Faculty of Biological Sciences \\ Quaid-i-Azam University \\ Islamabad, Pakistan \\ Shaukat Ali \\ Plant Biotechnology Program \\ National Agriculture Research Center \\ Park Road, Islamabad, Pakistan \\ Ghulam Muhammad Ali* \\ Plant Biotechnology Program \\ National Agriculture Research Center \\ Park Road, Islamabad, Pakistan \\ Tel: 92519255205 \\ E-mail: drgmali@yahoo.ca \\ Najma Ayub \\ Deparment of Microbiology/Biotechnology \\ Faculty of Biological Sciences \\ Quaid-i-Azam University \\ Islamabad, Pakistan \\ M. Shahid Masood \\ National Agriculture Research Center \\ Park Road, Islamabad, Pakistan
}

Keywords: 2,4-D, 2iP, BAP, callus induction, IAA, kinetin, regeneration, wheat.

Abbreviations: 2 4-D: 2,4-Dichlorophenoxyaceticacid
2iP: 6- $\gamma$ - $\gamma$-dimethylallylaminopurine
BAP: 6-BenzylAminoPurine
IAA: Indole-3-Acetic Acid

Four commercially grown wheat varieties of Pakistan, namely Inqilab-91, Chakwal-97, Tatara and Manthar were used for this investigation. For callus induction different concentrations of 2,4Dichlorophenoxyaceticacid (2,4-D) along with $0.1 \mathrm{mg} / \mathrm{L}$ of Kinetin were evaluated. For regeneration initially different concentrations of Indole-3-Acetic Acid (IAA) and 6-BenzylAminoPurine (BAP) were tested. Best hormone combinations were further subjected to Kinetin and 6- $\gamma$ - $\gamma$-dimethylallylaminopurine (2iP). For Inqilab-91, Chakwal-97 and Manthar, $3 \mathrm{mg} / \mathrm{L}$ of 2,4-D was found optimum, which induced $83.25 \%, 77.75 \%$ and $95.20 \%$ of embryogenic calli, respectively. Maximum callus induction (97.18\%) was observed in Tatara when $2 \mathrm{mg} / \mathrm{L}$ of 2,4-D was used. As regard to regeneration, Inqilab-91, Chakwal-97 and Manthar showed maximum regeneration on media containing 0.1 $\mathrm{mg} / \mathrm{L}$ IAA, $0.4 \mathrm{mg} / \mathrm{L}$ Kinetin and $0.5 \mathrm{mg} / \mathrm{L} \mathrm{2iP,}$ regenerating $87.25 \%, 81.75 \%$ and $68.75 \%$ respectively. For Tatara maximum regeneration of $12.25 \%$ was obtained on $0.1 \mathrm{mg} / \mathrm{L}$ IAA and $2 \mathrm{mg} / \mathrm{L}$ of BAP. Presently optimized regeneration method holds promise for facilitating the deployment of agronomical important trait through genetic transformation for the improvement of this important food crop.

Wheat (Triticum spp.) belongs to grass family Poaceae and it is cultivated worldwide. It is self-pollinated annual plant and is the most widely grown cereal crop in the world (Zhou et al. 2003). Considerable efforts are being made to improve its productivity by using biotechnology.

Genetic transformation enables the introduction of novel genes directly into locally adapted cultivars to create new genetically modified varieties (Jones et al. 2005), using tissue culture protocols as their base line. These procedures

*Corresponding author 
require that a whole plant should be regenerated from isolated cells or tissues. Many protocols have been developed but in wheat they are very much genotypic dependent (Bhalla et al. 2006).

Both mature and immature embryos have been used extensively in tissue culture protocols, but mature embryos were found to be a better choice in comparison to immature embryos (Özgen et al. 1998). Immature embryos are better explant source when regeneration is considered, but they require time and growth facilities (Zale et al. 2004) whereas mature embryos are available throughout the year. Mature embryos can either be dissected (Yu et al. 2008) or used directly (Özgen et al. 1998).

Dicamba (Satyavathi et al. 2004), Picloran (He and Lazzeri, 2001), 2,4-Dichlorophenoxyaceticacid (2,4-D) etc. have been commonly used in history by many workers for embryogenic callus induction. Second step is the optimization of the medium on which maximum plantlets are regenerated. Indole-3-Acetic Acid (IAA), 6BenzylAminoPurine (BAP) and Kinetin were the most extensively used hormones (He and Lazzeri, 2001; Haliloglu, 2006). But others can also be used like Thidiazuron (Xueyan et al. 2000). There are several drawbacks associated with these growth regulators such as longer incubation period resulting in the loss of explants viability for regeneration and high cost etc. 6- $\gamma-\gamma-$ dimethylallylaminopurine (2iP) was used initially for regeneration, but then replaced with its cheaper synthetic analogue BAP (Varshney et al. 1997). 2iP had been used in some crops in the past (Rao et al. 1995; Qu et al. 2002).

The present study was initiated to assess the regeneration ability for four widely grown Pakistani spring wheat varieties i.e. Inqilab-91, Chakwal-97, Tatara and Manthar. The maximum number of plants regenerated in a minimum time period will facilitate more effectively to explore transgenics with better expression later on. We hope that this study will be useful for local as well as for international

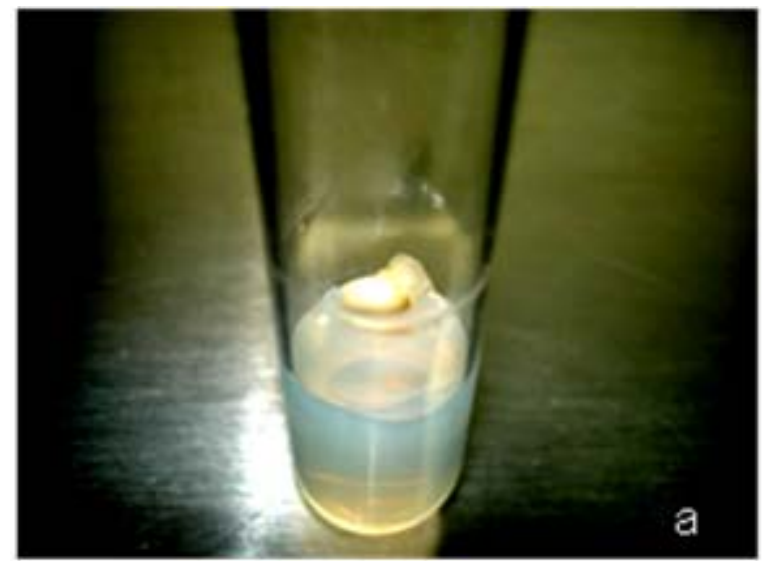

plant breeders for improving the regeneration efficiency of transgenic cells in wheat.

\section{MATERIALS AND METHODS}

\section{Plant materials}

Mature seeds of four varieties Inqilab-91, Chakwal-97, Tatara and Manthar were used as explants source for callus induction. They were surface sterilized by washing with tween-20 and 70\% ethanol for 30 sec, and finally with $40 \%$ sodium hypochlorite for $20 \mathrm{~min}$ followed by several washes with sterilized distilled water in order to remove excess of the chemical. After drying on filter paper these seeds were placed on sterilized Callus Induction Medium.

\section{Callus induction and regeneration}

Murashige and Skoog medium (Murashige and Skoog, 1962) was used for this study. Stocks were prepared and stored in refrigerator. Vitamin stock was also prepared in which thiamine, myoinositol, nicotinic acid, pyridoxine and glycine were added. Stocks of auxins, 2,4-D, IAA, and cytokinins BAP, 2iP and Kinetin were also prepared. These stocks were used for fresh medium preparation. $30 \mathrm{~g} / \mathrm{L}$ of sucrose as carbon source and $6 \mathrm{~g} / \mathrm{L}$ of agar as gelling agent were added to the medium and its $\mathrm{pH}$ was adjusted at 5.8. Fresh media was prepared and poured in test tubes or conical flasks and autoclaved at $121^{\circ} \mathrm{C}$ for $20 \mathrm{~min}$. For callus induction medium, four concentrations of 2,4-D (2 $\mathrm{mg} / \mathrm{L}, 3 \mathrm{mg} / \mathrm{L}, 4 \mathrm{mg} / \mathrm{L}, 5 \mathrm{mg} / \mathrm{L}$ ) with and without $0.1 \mathrm{mg} / \mathrm{L}$ of Kinetin were experimented. Seeds were cultured in these media and after three weeks calli were broken into almost $0.5 \mathrm{~cm}$ pieces which were shifted to maintenance medium containing $2 \mathrm{mg} / \mathrm{L}$ 2,4-D. After another two weeks, these proliferated calli were dissected into small pieces and transferred to regeneration medium containing different concentrations of growth regulators. Regeneration medium optimization protocols were divided into three stages. In the first stage regeneration was tested on medium containing

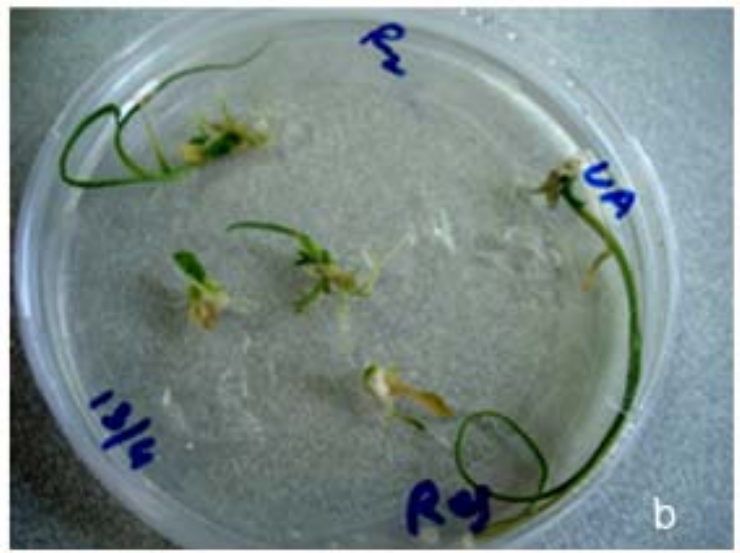

Figure 1. Callus induction and regeneration in different varieties of wheat.

(a) Callus induction in Inqilab-91 on medium containing $3 \mathrm{mg} / \mathrm{L}$ 2,4- D.

(b) Regeneration in Inqilab-91 on medium containing $0.1 \mathrm{mg} / \mathrm{L}$ IAA, $0.4 \mathrm{mg} / \mathrm{L}$ Kinetin and $0.5 \mathrm{mg} / \mathrm{L}$ 2iP. 
different concentrations of IAA $(0,0.1 \mathrm{mg} / \mathrm{L}, 0.2 \mathrm{mg} / \mathrm{L}$, and $0.3 \mathrm{mg} / \mathrm{L})$ and BAP $(0,1 \mathrm{mg} / \mathrm{L}, 1.5 \mathrm{mg} / \mathrm{L}, 2 \mathrm{mg} / \mathrm{L}, 2.5$ $\mathrm{mg} / \mathrm{L}$ ). Data was analyzed and compared. Best combination of the two growth regulators for each variety was chosen separately. In the second stage best selected combination of IAA and BAP, along with each of the regulator separately was tested with different concentrations of Kinetin (0, 0.1 $\mathrm{mg} / \mathrm{L}, 0.2 \mathrm{mg} / \mathrm{L}, 0.3 \mathrm{mg} / \mathrm{L}, 0.4 \mathrm{mg} / \mathrm{L}$ ). Data was analyzed and the best combination of growth regulators for each variety was chosen separately. Finally the best combinations along with each growth regulator alone, was assayed with different concentrations of $2 \mathrm{iP}(0,0.5 \mathrm{mg} / \mathrm{L}, 1$ $\mathrm{mg} / \mathrm{L}, 1.5 \mathrm{mg} / \mathrm{L})$. Cultures were shifted to growth room in which temperature was maintained at $26^{\circ} \mathrm{C}$, with $16 \mathrm{hrs}$ light cycle in every 24 hrs.

Four replications, in which hundred explants per replication for callus induction and 70 calli per replication for regeneration, were used for each treatment of callus induction and regeneration. Callus induction, callus size and callus weight were estimated. For regeneration only percentage was estimated. Two factors completely randomized design was used in each experiment. Data was analyzed and compared at 0.01 probability level (Table 1 ).

\section{RESULTS AND DISCUSSION}

\section{Callus induction}

Mature seeds of all four genotypes were inoculated in eight combinations of callus induction medium containing 2,4-D with or without Kinetin. Embryos of all four genotypes swelled up after just two days of inoculation and calli emerged afterwards. Embryogenic calli produced were nodular and compact, which is in agreement with the finding of Ozias-Akins and Vasil (1982) who identified these nodular structures as embryoids. Kinetin has negative effect on callus induction. Most of the calli produced in the presence of kinetin were from root tips, which were of no use in this research.

For Inqilab-91, production of embryogenic calli increased from $35.08 \%$ to $83.25 \%$ (Figure 1) as the 2,4-D was increased from $2 \mathrm{mg} / \mathrm{L}$ to $3 \mathrm{mg} / \mathrm{L}$ (Table 2). Further increase in the auxins reduced the percentage of embryogenic calli production. Callus weight was increased from $0.17 \mathrm{~g}$ to $0.62 \mathrm{~g}$ when the growth regulator was increased up to $4 \mathrm{mg} / \mathrm{L}$ (Table 2) but this heavy callus was slimy and non embryogenic. Callus weight decrease by further increasing 2,4-D. Similarly, callus size was also increased from $0.6 \mathrm{~cm}$ to $1.28 \mathrm{~cm}$, when concentration was increased up to $4 \mathrm{mg} / \mathrm{L}$ (Table 2). Effect of Kinetin was negative on embryogenic callus induction, except for the concentration $2 \mathrm{mg} / \mathrm{L}$ of 2,4-D where its effect was almost negligible (Table 2). In remaining concentrations percentage of embryogenic calli was decreased drastically as in case of $3 \mathrm{mg} / \mathrm{L}$ of 2,4-D, the percentage decreased from $83.25 \%$ to $48.5 \%$. Callus weight and size also decreased with the addition of Kinetin up to $4 \mathrm{mg} / \mathrm{L}$ of 2,4$\mathrm{D}$, but it increased from $0.14 \mathrm{gm}$ to $0.82 \mathrm{gm}$ and $0.85 \mathrm{~cm}$ to $1.85 \mathrm{~cm}$ when Kinetin was added to $5 \mathrm{mg} / \mathrm{L}$ of the growth regulator (Table 2).

Similar results were obtained when we used Chakwal-97. Callus induction was increased from $36.03 \%$ to $77.75 \%$ (Figure 2) when concentration of 2,4-D was enhanced from $2 \mathrm{mg} / \mathrm{L}$ to $3 \mathrm{mg} / \mathrm{L}$ (Table 2). With the further increase in 2,4-D the embryogenic callus production was decreased. Callus weight in Chakwal-97 increased from $0.17 \mathrm{~g}$ to 0.36 $\mathrm{g}$ and callus size increased from $0.78 \mathrm{~cm}$ to $0.95 \mathrm{~cm}$ when concentration of 2,4-D was increased from $2 \mathrm{mg} / \mathrm{L}$ to 4 $\mathrm{mg} / \mathrm{L}$ (Table 2). Effect of Kinetin in Chakwal-97 was similar to Inqilab-91. Kinetin has almost no prominent effect when added to $2 \mathrm{mg} / \mathrm{L}$ of 2,4-D. At higher dose of
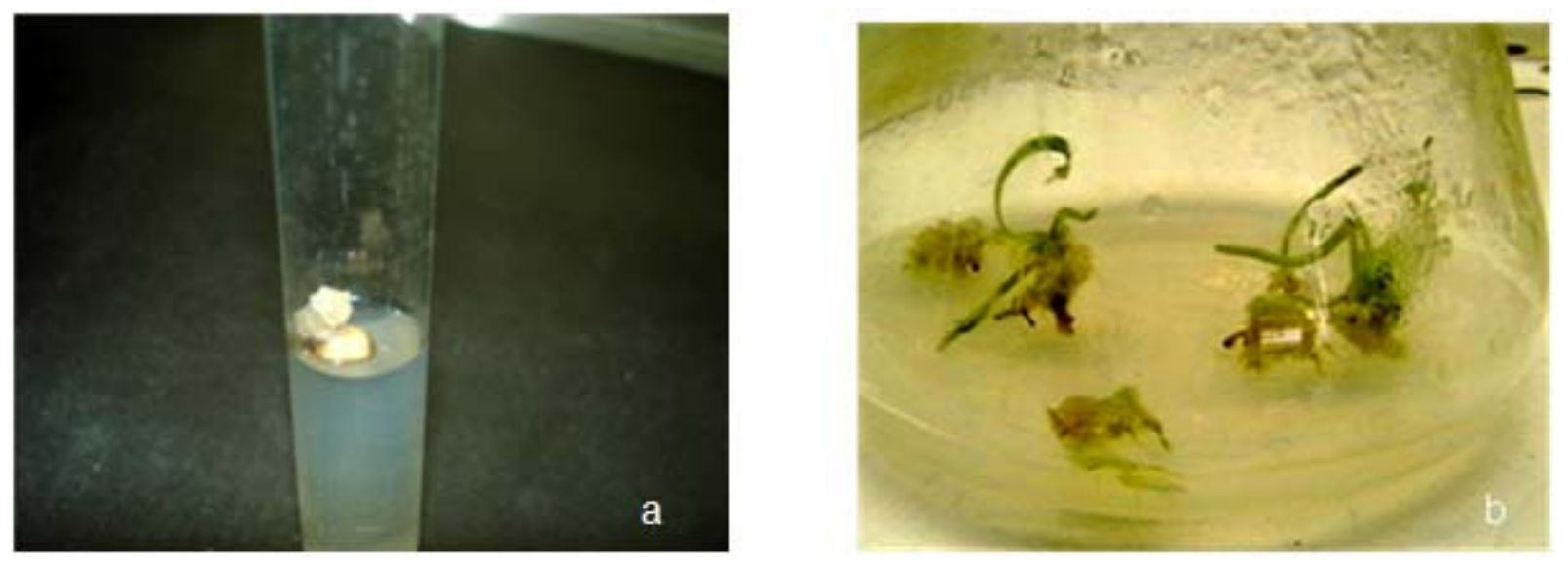

Figure 2. Callus induction and regeneration in different varieties of wheat.

(a) Callus induction in Chakwal-97 on media containing $3 \mathrm{mg} / \mathrm{L} 2,4-\mathrm{D}$.

(b) Regeneration in Chakwal-97 on medium containing, $0.1 \mathrm{mg} / \mathrm{L} \mathrm{IAA}, 0.4 \mathrm{mg} / \mathrm{L}$ Kinetin and $0.5 \mathrm{mg} / \mathrm{L}$ 2iP. 
2,4-D, Kinetin gave negative effect, as in the case of 3 $\mathrm{mg} / \mathrm{L}$, where addition of Kinetin reduced the callus induction from $77.75 \%$ to $41.00 \%$ (Table 2). Callus weight and size also decreased with the addition of Kinetin, but at $5 \mathrm{mg} / \mathrm{L} 2,4-\mathrm{D}$ callus weight increased from $0.21 \mathrm{gm}$ to 0.37 gm and callus size increased from $0.73 \mathrm{~cm}$ to $2.05 \mathrm{~cm}$ (Table 2), however these were not embryogenic.

Tatara was the most responsive variety for callus induction (Figure 3) where 97.18\% calli were produced when $2 \mathrm{mg} / \mathrm{L}$ of 2,4-D was used (Table 2). Two and $3 \mathrm{mg} / \mathrm{L}$ of this growth regulator decreased calli percentage whereas 5 $\mathrm{mg} / \mathrm{L}$ of 2,4-D increased the callus induction percentage to 91.8\% (Figure 3 and Table 2). Kinetin had a negative effect on callus induction, callus weight and callus size at $2 \mathrm{mg} / \mathrm{L}$, $3 \mathrm{mg} / \mathrm{L}$ and $4 \mathrm{mg} / \mathrm{L}$ of 2,4-D but at $5 \mathrm{mg} / \mathrm{L}$ callus weight increased from $0.65 \mathrm{gm}$ to $0.91 \mathrm{gm}$ and callus size increased from $1.52 \mathrm{~cm}$ to $1.8 \mathrm{~cm}$ whereas callus percentage decreased from $91.8 \%$ to $25 \%$ (Table 2).

In Manthar, the highest percentage of embryogenic calli were induced on $3 \mathrm{mg} / \mathrm{L}$ and $5 \mathrm{mg} / \mathrm{L}$ of 2,4-D, 95.83\% and 95.2\%, respectively (Table 2). Thereafter calli percentage decreased with further addition of growth regulator. Kinetin had negative effect on callus induction, callus weight and callus size, at $2 \mathrm{mg} / \mathrm{L}, 3 \mathrm{mg} / \mathrm{L}$ and $4 \mathrm{mg} / \mathrm{L}$ of 2,4-D. It had a positive effect at $5 \mathrm{mg} / \mathrm{L}$ for callus weight and size as weight increased from $0.26 \mathrm{gm}$ to $0.62 \mathrm{gm}$ and callus size increased from $0.88 \mathrm{~cm}$ to $1.6 \mathrm{~cm}$, but callus percentage

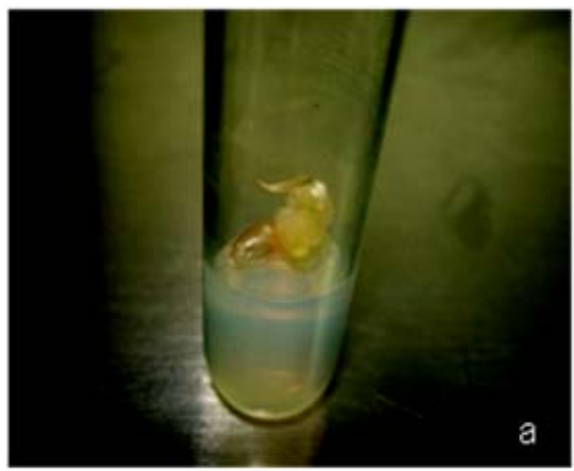

decreased from 95.2\% to 9\% (Table 2).

Turhan and Baser (2004) obtained best results by using 4 $\mathrm{mg} / \mathrm{L}$ of 2,4-D, but they added NAA at the concentration of $1 \mathrm{mg} / \mathrm{L}$. These concentrations do not coincide with present study. Shah et al. (2003) found excellent callus induction in wheat at $3.5 \mathrm{mg} / \mathrm{L}$ and good callus induction at $3 \mathrm{mg} / \mathrm{L}$ of 2,4-D. These results match with the present study in which $3 \mathrm{mg} / \mathrm{L}$ was found good for callus induction in Inqilab-91, Chakwal-97 and Manthar. Haliloglu (2006) supplemented Murashige and Skoog medium with $2 \mathrm{mg} / \mathrm{L}$ 2,4-D and produced 96\% embryogenic calli in Bobwhite. These results are similar to the results shown by Tatara, which showed maximum callus induction at $2 \mathrm{mg} / \mathrm{L}$ of 2,4-D. Sarker and Biswas (2002) tested different concentrations of 2,4-D for callus induction in wheat and found $6 \mathrm{mg} / \mathrm{L}$ as best concentration for callus induction from seeds which was not in accordance to our results since higher concentration than $3 \mathrm{mg} / \mathrm{L}$ produced non embryogenic calli. This study suggests that genotypic factor seems to be operating in response of particular concentrations of growth regulators.

\section{Plant regeneration}

When embryogenic calli were shifted to maintenance medium they proliferated. Some of the calli turned green in maintenance medium. These maintained calli were then transferred to regeneration medium. On MS medium

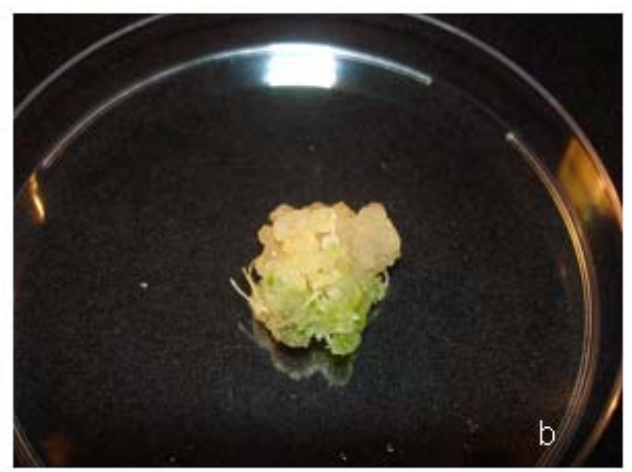

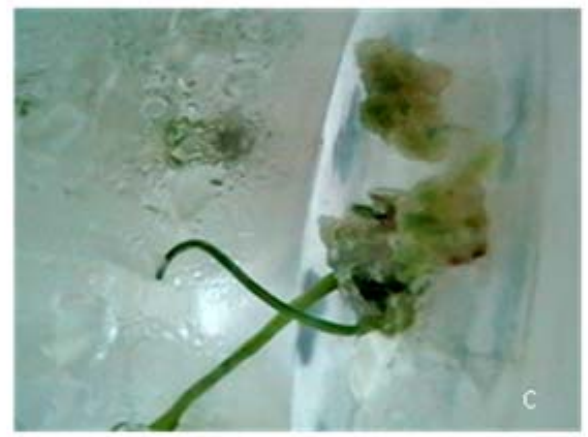

Figure 3. Callus induction and regeneration in different varieties of wheat.

(a) Callus induction in Tatara on $5 \mathrm{mg} / \mathrm{L}$ of 2,4-D.

(b) Maintained callus of Tatara on $2 \mathrm{mg} / \mathrm{L}$ of 2,4-D.

(c) Regeneration in Tatara on medium containing $0.1 \mathrm{mg} / \mathrm{L} \mathrm{IAA}$ and $2 \mathrm{mg} / \mathrm{L}$ BAP. 

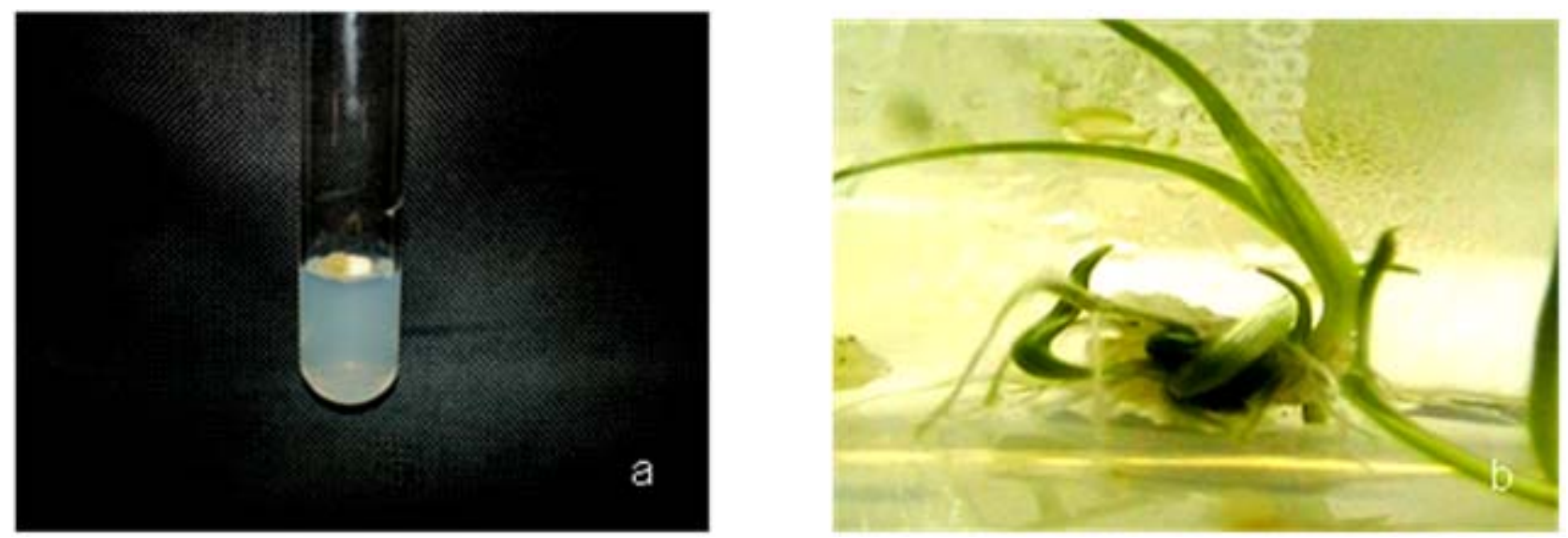

Figure 4. Callus induction and regeneration in different varieties of wheat.

(a) Callus induction in Manthar on medium containing $3 \mathrm{mg} / \mathrm{L}$ of 2,4-D.

(b) Regeneration in Manthar on medium containing $0.1 \mathrm{mg} / \mathrm{L} \mathrm{IAA}, 0.4 \mathrm{mg} / \mathrm{L}$ Kinetin and $0.5 \mathrm{mg} / \mathrm{L}$ 2iP.

without growth regulators some green spotting appeared, but after few days these calli turned brown, and died. BAP itself and IAA itself showed negative results and induced browning in calli. When BAP was added to different doses of IAA, there was no effect on regeneration and calli showed extensive rooting, similar to when IAA was used alone. At the dose of $0.1 \mathrm{mg} / \mathrm{L}$ IAA calli responded well with different concentrations of BAP (Table 3). Chakwal97, Tatara (Figure 3) and Manthar gave maximum response at $2 \mathrm{mg} / \mathrm{L}$ of BAP with $67 \%, 12.25 \%$ and $43.5 \%$, respectively of plant regeneration (Table 3 and Table 4). For BAP, Inqilab-91 gave highest percentage of regeneration at $2.5 \mathrm{mg} / \mathrm{L}$ of BAP (71.75\%) (Table 3). Kinetin alone in MS medium showed some green spotting, but no shoot was produced. When Kinetin was added to the optimized doses of IAA and BAP together, regeneration was decreased. Regeneration percentage decreased from 72 to 0 for Inqilab-91, 70 to 0 for Chakwal-97, 12.25 to 0 for Tatara and 49.25 to 0 for Manthar, as concentration of Kinetin was increased gradually (Table 4).

The combination of BAP and Kinetin had no response in Tatara and Manthar varieties, not even green spotting appeared. This combination regenerated $41.25 \%$ in Inqilab91, whereas $11.75 \%$ of plants regenerated in Chakwal-97 (Table 4). Results also showed that the most responsive concentration of Kinetin was $0.4 \mathrm{mg} / \mathrm{L}$. With this concentration of Kinetin, optimized concentration of IAA responded very well. In Inqilab-91, Chakwal-97 and Manthar, Kinetin and IAA gave good results. At $0.1 \mathrm{mg} / \mathrm{L}$ of IAA and $0.4 \mathrm{mg} / \mathrm{L}$ of Kinetin regeneration percentage was 80.25, 73 and 61.5 in Inqilab-91, Chakwal-97 and Manthar, respectively (Table 4). From this it can be deduced that regeneration in Inqilab-91, Chakwal-97 and Manthar was improved by replacing Kinetin with BAP. But in Tatara, results almost remain the same.

When 2iP was added to plain MS medium did not produce plants in any of the four genotypes. Calli turned brown within a week. $2 \mathrm{iP}$ in combination with IAA produced extensive rooting but $1 \mathrm{mg} / \mathrm{L}$ of this hormone responded well in Inqilab-91 and Chakwal-97. In Tatara, this combination responded very poorly, and most of the calli produced roots instead of shoots. In Manthar IAA with 0.5 $\mathrm{mg} / \mathrm{L}$ of $2 \mathrm{iP}$ rendered $19.75 \%$ regeneration. Combination of 2iP with BAP showed no results at all, and all the calli turned brown within a week. Combination of Kinetin and 2iP showed poor regeneration, but interestingly all combinations regenerated plants. When BAP was added to this medium, no plants were regenerated and calli turned brown. Its effect was similar to Kinetin, when it was used in combination with IAA and BAP, where regeneration frequency decreased. The most efficient combination for Inqilab-91, Chakwal-97 and Manthar was 2iP with Kinetin and IAA (Figure 1, Figure 2 and Figure 4). Almost all calli turned green within a week and shoots started to emerge after two weeks. The most unique aspect of this combination was that roots also started after two weeks, but growth was very slow. Regeneration of these three genotypes, namely Inqilab-91, Chakwal-97 and Manthar were improved to $87.25,81.75$ and 68.75 respectively (Table 5). Tatara gave negative result with 2iP and its regeneration frequency was decreased from 9.5 to 0 (Table 5) when dose of $2 \mathrm{iP}$ was increased from 0 to $1.5 \mathrm{mg} / \mathrm{L}$. From these results it is confirmed that tissue culture studies in wheat are very much genotype dependent. Present study is in accordance to Alizadeh et al. (2004) when IAA is taken under consideration, but their concentration was different. He also used $1 \mathrm{mg} / \mathrm{L}$ of BAP and $0.2 \mathrm{mg} / \mathrm{L}$ of 2,4$\mathrm{D}$ for shoot regeneration in embryo explants and $0.2 \mathrm{mg} / \mathrm{L}$ 2,4-D and $2 \mathrm{mg} / \mathrm{L}$ BAP for shoot regeneration in excised embryo explants of cultivars Tajan and Azadi. Shah et al. (2003) found $2 \mathrm{mg} / \mathrm{L}$ BAP and $1.0 \mathrm{mg} / \mathrm{L}$ IAA as best combination for plantlet regeneration as well as $1.0 \mathrm{mg} / \mathrm{L}$ BAP and $0.5 \mathrm{mg} / \mathrm{L} 2,4-\mathrm{D}$. They also found good response when Kinetin was added to the regeneration medium. These results are in agreement with the results of Sarker and Biswas (2002) who used $0.5 \mathrm{mg} / \mathrm{l}$ of Kinetin and obtained 
best results. Ozias-Akins and Vasil (1982) showed that Kinetin at the concentration of $0.1-1 \mathrm{mg} / \mathrm{L}$ can produce maximum number of plants from embryogenic calli, which is similar to our research where Kinetin has positive response in almost all combinations. The incorporation of only Kinetin in the regeneration medium produced plants (Rahman et al. 2008), whereas in this study only green spotting occurred, but no shoots were produced. $2 \mathrm{iP}$ at the concentration of $1 \mathrm{mg} / \mathrm{L}$ was used by Zamora and Scott (1983) to regenerate plants from calli derived from 2,4-D containing medium, which is in accordance with this study but they have used 2,4-D in regeneration medium. OziasAkins and Vasil (1982) also produced plants from the same concentration of $2 \mathrm{iP}$ and 2,4-D from calli derived from inflorescences.

As far as explant is concerned these results are similar to many researchers, as Zale et al. (2004) who also proved that mature embryos can produce sufficient number of regenerated plants. These results are also in agreement with Özgen et al. (1998), according to whom mature embryos have a high frequency of callus induction and regeneration capacity, therefore, being available through out the year, can be used in wheat tissue culture. Delporte et al. (2001) used mature embryos, successfully and produced calli, which is in agreement with this research, but instead of using the whole seed or embryo, they have used fragments of embryos. Yu et al. (2008) also used mature embryos in wheat tissue culture.

We reported here some valuable clues such as the impact of $2 \mathrm{iP}$ and Kinetin resulting in improved regeneration of wheat cultivars. It is hoped that these will serve as beacon light for plant scientists to achieve a higher number of plants in the wheat transgenesis.

\section{REFERENCES}

ALIZADEH, H.; NAGHAVI, M.R.; OMIDI, M. and SAATIAN, B. Effect of plant growth regulators on direct shoot regeneration of wheat (Triticum aestivum). In: New directions for a diverse planet: Proceedings of the $4^{\text {th }}$ International Crop Science Congress. $\left(26^{\text {th }}\right.$ September $-1^{\text {st }}$ October, 2004,Brisbane, Australia).

BHALLA, Prem L.; OTTENHOF, Harald H. and SINGH, Mohan B. Wheat transformation - an update of recent progress. Euphytica, June 2006, vol. 149, no. 3, p. 353-366.

DELPORTE, F.; MOSTADE, O. and JACQUEMEN, J.M. Plant regeneration through callus initiation from thin mature embryo fragments of wheat (Triticum aestivum) genotypes. Plant Cell, Tissue and Organ Culture, October 2001, vol. 67, no. 1, p. 73-80.

HALILOGLU, K. Efficient regeneration system from wheat leaf base segments. Biologia Plantarum, September 2006, vol. 50, no. 3, p. 326-330.
HE, G.Y. and LAZZERI, P.A. Improvement of somatic embryogenesis and plant regeneration from durum wheat (Triticum turgidum var. durum Desf.) scutellum and inflorescence cultures. Euphytica, May 2001, vol. 119, no. 3, p. 369-376.

JONES, Huw D.; DOHERTY, Angela and HUIXIA, Wu. Review of methodologies and a protocol for the Agrobacterium-mediated transformation of wheat. Plant Methods, September 2005, vol. 1, no. 5.

MURASHIGE, Toshio and SKOOG, Folke. A revised medium for rapid growth and bioassays with tobacco tissue cultures. Physiologia Plantarum, July 1962, vol. 15, no. 3, p. 473-497.

ÖZGEN, M.; TURET, M.; ALTINOK, S. and SANCAK, C. Efficient callus induction and plant regeneration from mature embryo culture of winter wheat (Triticum aestivum L.) genotypes. Plant Cell Reports, December 1998, vol. 18, no. 3-4, p. 331-335.

OZIAS-AKINS, Peggy and VASIL, Indra K. Plant regeneration from cultured immature embryos and inflorescences of Triticum aestivum L. (wheat): Evidence for somatic embryogenesis. Protoplasma, June 1982, vol. 110, no. 2, p. 95-105.

QU, Luping; CHEN, Jianjn; HENNY, Richard J.; HUANG, Yingfeng; CALDWELL, Russell D. and ROBINSON, Cynthia A. Thidiazuron promotes adventitious shoot regeneration from pothos (Epipremnum aureum) leaf and petiole explants. In Vitro Cellular and Developmental Biology-Plant, May 2002, vol. 38, no. 3, p. 268-271.

RAHMAN, M.M.; SHAMSUDDIN, A.K.M. and ASAD, $\mathrm{U}$. In vitro regeneration from mature embryos in spring wheat. International Journal of Sustainable Crop Production, February 2008, vol. 3, no. 2, p. 76-80.

RAO, A.M.; PADMA SREE, K. and KAVI KISHOR, P.B. Enhanced plant regeneration in grain and sweet sorghum by asparagine, proline and cefotaxime. Plant Cell Reports, January 1995, vol. 15, no. 1-2, p. 72-75.

SARKER, R.H. and BISWAS, A. In vitro plantlet regeneration and Agrobacterium-mediated genetic transformation of wheat (Triticum aestivum L.). Plant Tissue Culture, December 2002, vol. 12, no. 2, p. 155-165.

SATYAVATHI, V.V.; JAUHAR, P.P.; ELIAS, E.M. and RAO, M.B. Effects of growth regulators on in vitro plant regeneration in durum wheat. Crop Science, SeptemberOctober 2004, vol. 44, no. 5, p. 1839-1846.

SHAH, M.I.; JABEEN, M. and ILAHI, I. In vitro callus induction, its proliferation and regeneration in seed explants of wheat (Triticum aestivum L.) var. LU-26S. Pakistan Journal of Botany, June 2003, vol. 35, no. 2, p. 209-217. 
TURHAN, H. and BASER, I. Callus induction from mature embryo of winter wheat (Triticum aestivum L.). Asian Journal of Plant Sciences, 2004, vol. 3, no. 1, p. 17-19.

VARSHNEY, A.; KANT, T. and KOTHARI, S.L. Plant regeneration from coleoptile tissue of wheat (Triticum aestivum). Biologia Plantarum, July 1997, vol. 40, no. 1, p. 137-141.

XUEYAN, Shan; DESEN, Li and RONGDA, Qu. Thidiazuron promotes in vitro regeneration of wheat and barley. In Vitro Cellular and Developmental Biology-Plant, May 2000, vol. 36, no. 3, p. 207-210.

YU, Y.; WANG, J.; ZHU, M.L. and WEI, Z.M. Optimization of mature embryos based high frequency callus induction and plant regeneration from elite wheat cultivars grown in China. Plant Breeding, June 2008, vol. 127, no. 3, p. 249-255.

ZALE, Janice M.; BORCHARDT-WIER, Harmony; KIDWELL, Kimberly K. and STEBER, Camille M. Callus induction and plant regeneration from mature embryos of a diverse set of wheat genotypes. Plant Cell, Tissue and Organ Culture, March 2004, vol. 76, no. 3, p. 277-281.

ZAMORA, A.B. and SCOTT, K.J. Callus formation and plant regeneration from wheat leaves. Plant Science Letters, April 1983, vol. 29, no. 2-3, p. 183-189.

ZHOU, H.; BERG, J.D.; BLANK, S.E.; CHAY, C.A.; CHEN, G.; ESKELSEN, S.R.; FRY, J.E.; HOI, S.; HU, T.; ISAKSON, P.J.; LAWTON, M.B.; METZ, S.G.; REMPEL, C.B.; RYERSON, D.K.; SANSONE, A.P.; SHOOK, A.L.; STARKE, R.J.; TICHOTA, J.M. and VALENTI, S.A. Field efficacy assessment of transgenic Roundup Ready wheat. Crop Science, May-June 2003, vol. 43, no. 3, p. 1072-1075. 


\section{APPENDIX}

\section{TABLES}

Table 1. ANOVA of four genotypes with 68 treatments for regeneration.

\begin{tabular}{|c|c|c|c|c|c|c|}
\hline K value & Source & $\begin{array}{c}\text { Degrees of } \\
\text { Freedom }\end{array}$ & Sum of Squares & Mean Square & F value & Prob \\
\hline 2 & Factor A & 3 & 25285.680 & 8428.560 & 3041.2138 & 0.0000 \\
\hline 4 & Factor B & 67 & 297371.467 & 4438.380 & 1601.4672 & 0.0000 \\
\hline 6 & AB & 201 & 103483.320 & 514.842 & 185.7667 & 0.0000 \\
\hline-7 & Error & 816 & 2261.500 & 2.771 & & \\
\hline
\end{tabular}

Coefficient of Variation $19.57 \%$. 
Table 2. Callus induction percentage on different combinations of 2,4-D and $\mathbf{0 . 1} \mathrm{mg} / \mathrm{L}$ Kinetin. Letters indicate the comparison of different treatments.

\begin{tabular}{|c|c|c|c|c|c|c|c|c|c|}
\hline Cultivars & $\begin{array}{l}\text { Callus } \\
\text { profile }\end{array}$ & $\underset{D}{2 \mathrm{mg} / \mathrm{L} 2,4-}$ & $\begin{array}{l}2 \mathrm{mg} / \mathrm{L} \\
2,4-\mathrm{D}+ \\
\text { Kinetin }\end{array}$ & $\begin{array}{c}3 \mathrm{mg} / \mathrm{L} \\
2,4-D\end{array}$ & $\begin{array}{l}3 \mathrm{mg} / \mathrm{L} \\
2,4-\mathrm{D}+ \\
\text { Kinetin }\end{array}$ & $\begin{array}{c}4 \mathrm{mg} / \mathrm{L} \\
2,4-\mathrm{D}\end{array}$ & $\begin{array}{l}4 \mathrm{mg} / \mathrm{L} 2,4- \\
\mathrm{D}+\text { Kinetin }\end{array}$ & $\underset{D}{5 \mathrm{mg} / \mathrm{L} 2,4-}$ & $\begin{array}{l}5 \mathrm{mg} / \mathrm{L} \\
2,4-\mathrm{D}+ \\
\text { Kinetin }\end{array}$ \\
\hline \multirow{3}{*}{ Inqilab-91 } & $\begin{array}{l}\text { Callus } \\
\text { Induction }\end{array}$ & $35.08^{\text {efghi }}$ & $36.5^{\mathrm{efg}}$ & $83.25^{\mathrm{abc}}$ & $48.5^{\mathrm{de}}$ & $16.75^{\mathrm{jkl}}$ & $10.25^{\mathrm{kl}}$ & $33.10^{\text {fghi }}$ & $5.15^{\prime}$ \\
\hline & $\begin{array}{l}\text { Callus } \\
\text { Weight }\end{array}$ & $0.17^{\mathrm{mno}}$ & $0.11^{\circ}$ & $0.50^{\mathrm{fg}}$ & $0.27^{\mathrm{jklm}}$ & $0.62^{\mathrm{de}}$ & $0.29^{\mathrm{jkl}}$ & $0.14^{\text {no }}$ & $0.82^{\mathrm{ab}}$ \\
\hline & Callus Size & $0.60^{\mathrm{kl}}$ & $0.20^{\circ}$ & $1.18^{\mathrm{h}}$ & $0.60^{\mathrm{kl}}$ & $1.28^{\mathrm{gh}}$ & $0.60^{\mathrm{kl}}$ & $0.85^{\mathrm{ij}}$ & $1.85^{\mathrm{ab}}$ \\
\hline \multirow{3}{*}{ Chakwal-97 } & $\begin{array}{l}\text { Callus } \\
\text { Induction }\end{array}$ & $36.03^{\text {efgh }}$ & $43.50^{\text {def }}$ & $77.75^{\mathrm{bc}}$ & $41.00^{\text {def }}$ & $14.25^{\mathrm{jkl}}$ & $10.50^{\mathrm{kl}}$ & $34.63^{\text {efghi }}$ & $21.65^{\mathrm{ijk}}$ \\
\hline & $\begin{array}{l}\text { Callus } \\
\text { Weight }\end{array}$ & $0.17^{\mathrm{mno}}$ & $0.11^{\circ}$ & $0.36^{\text {hijk }}$ & $0.20^{\operatorname{lmno}}$ & $0.33^{\mathrm{ijk}}$ & $0.20^{\operatorname{Imno}}$ & $0.21^{\operatorname{Imno}}$ & $0.37^{\mathrm{hij}}$ \\
\hline & Callus Size & $0.78^{\mathrm{ijk}}$ & $0.23^{\text {no }}$ & $0.93^{\mathrm{ij}}$ & $0.38^{\mathrm{mno}}$ & $0.95^{i}$ & $0.43^{\mathrm{Imn}}$ & $0.73^{\mathrm{jk}}$ & $2.05^{\mathrm{a}}$ \\
\hline \multirow{3}{*}{ Tatara } & $\begin{array}{l}\text { Callus } \\
\text { Induction }\end{array}$ & $97.18^{\mathrm{a}}$ & $52.08^{d}$ & $69.38^{c}$ & $45.50^{\text {def }}$ & $22.13^{\mathrm{hijk}}$ & $14.60^{\mathrm{jkl}}$ & $91.80^{a b}$ & $25.00^{\text {ghij }}$ \\
\hline & $\begin{array}{l}\text { Callus } \\
\text { Weight }\end{array}$ & $0.53^{\text {efg }}$ & $0.37^{\mathrm{hij}}$ & $0.57^{\mathrm{def}}$ & $0.25^{\mathrm{klmn}}$ & $0.62^{\mathrm{de}}$ & $0.47^{\mathrm{fgh}}$ & $0.65^{d}$ & $0.91^{\mathrm{a}}$ \\
\hline & Callus Size & $1.20^{\mathrm{h}}$ & $0.80^{\mathrm{ijk}}$ & $1.18^{\mathrm{h}}$ & $0.60^{\mathrm{kl}}$ & $1.35^{\mathrm{fgh}}$ & $0.80^{\mathrm{ijk}}$ & $1.52^{\mathrm{def}}$ & $1.80^{\mathrm{bc}}$ \\
\hline \multirow{3}{*}{ Manthar } & $\begin{array}{l}\text { Callus } \\
\text { Induction }\end{array}$ & $76.85^{c}$ & $42.88^{\mathrm{def}}$ & $95.83^{\mathrm{a}}$ & $52.05^{d}$ & $44.50^{\text {def }}$ & $25.08^{\text {ghij }}$ & $95.20^{\mathrm{a}}$ & $9.000^{\mathrm{kl}}$ \\
\hline & $\begin{array}{l}\text { Callus } \\
\text { Weight }\end{array}$ & $0.77^{\mathrm{bc}}$ & $0.67^{\mathrm{cd}}$ & $0.44^{\mathrm{ghi}}$ & $0.27^{\mathrm{jklm}}$ & $0.66^{c d}$ & $0.26^{\mathrm{jklm}}$ & $0.26^{\mathrm{jklm}}$ & $0.62^{\mathrm{de}}$ \\
\hline & Callus Size & $1.30^{g h}$ & $0.75^{\mathrm{ijk}}$ & $1.70^{\mathrm{bcd}}$ & $0.50^{\mathrm{Im}}$ & $1.42^{\mathrm{efg}}$ & $0.38^{\mathrm{mno}}$ & $0.88^{\mathrm{ij}}$ & $1.60^{\text {cde }}$ \\
\hline
\end{tabular}


Table 3. Regeneration percentage on different combinations of IAA and BAP. Letters indicate the comparison of different treatments.

\begin{tabular}{|c|c|c|c|c|c|c|c|}
\hline & \multirow{2}{*}{$\begin{array}{l}\text { Cultivars } \\
\text { (Genotypic } \\
\text { means) }\end{array}$} & \multicolumn{6}{|c|}{ Benzyl Amino Purine } \\
\hline & & & $0 \mathrm{mg} / \mathrm{L}$ & $1.0 \mathrm{mg} / \mathrm{L}$ & $1.5 \mathrm{mg} / \mathrm{L}$ & $2.0 \mathrm{mg} / \mathrm{L}$ & $2.5 \mathrm{mg} / \mathrm{L}$ \\
\hline \multirow{16}{*}{ 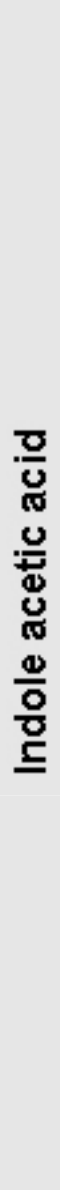 } & \multirow{4}{*}{$\begin{array}{l}\text { Inqilab-91 } \\
(9.738)\end{array}$} & $0 \mathrm{mg} / \mathrm{L}$ & $0.0^{\prime}$ & $0.0^{1}$ & $0.0^{1}$ & $0.0^{\prime}$ & $0.0^{\prime}$ \\
\hline & & $0.1 \mathrm{mg} / \mathrm{L}$ & $0.0^{\prime}$ & $8.5^{\mathrm{j}}$ & $54.5^{d}$ & $60.0^{c}$ & $71.75^{\mathrm{a}}$ \\
\hline & & $0.2 \mathrm{mg} / \mathrm{L}$ & $0.0^{1}$ & $0.0^{1}$ & $0.0^{1}$ & $0.0^{1}$ & $0.0^{1}$ \\
\hline & & $0.3 \mathrm{mg} / \mathrm{L}$ & $0.0^{1}$ & $0.0^{1}$ & $0.0^{1}$ & $0.0^{1}$ & $0.0^{1}$ \\
\hline & \multirow{4}{*}{$\begin{array}{c}\text { Chakwal-97 } \\
\text { (8.6) }\end{array}$} & $0 \mathrm{mg} / \mathrm{L}$ & $0.0^{1}$ & $0.0^{1}$ & $0.0^{1}$ & $0.0^{1}$ & $0.0^{1}$ \\
\hline & & $0.1 \mathrm{mg} / \mathrm{L}$ & $0.0^{1}$ & $11.0^{\mathrm{i}}$ & $51.0^{\mathrm{e}}$ & $67.0^{\mathrm{b}}$ & $43.0^{f}$ \\
\hline & & $0.2 \mathrm{mg} / \mathrm{L}$ & $0.0^{\prime}$ & $0.0^{1}$ & $0.0^{1}$ & $0.0^{1}$ & $0.0^{\prime}$ \\
\hline & & $0.3 \mathrm{mg} / \mathrm{L}$ & $0.0^{\prime}$ & $0.0^{\prime}$ & $0.0^{\prime}$ & $0.0^{1}$ & $0.0^{1}$ \\
\hline & \multirow{4}{*}{$\begin{array}{c}\text { Tatara } \\
(1.263)\end{array}$} & $0 \mathrm{mg} / \mathrm{L}$ & $0.0^{\prime}$ & $0.0^{1}$ & $0.0^{1}$ & $0.0^{1}$ & $0.0^{\prime}$ \\
\hline & & $0.1 \mathrm{mg} / \mathrm{L}$ & $0.0^{\prime}$ & $0.0^{\prime}$ & $6.0^{k}$ & $11.25^{\mathrm{i}}$ & $8.0^{\mathrm{j}}$ \\
\hline & & $0.2 \mathrm{mg} / \mathrm{L}$ & $0.0^{1}$ & $0.0^{1}$ & $0.0^{1}$ & $0.0^{1}$ & $0.0^{1}$ \\
\hline & & $0.3 \mathrm{mg} / \mathrm{L}$ & $0.0^{1}$ & $0.0^{\prime}$ & $0.0^{\prime}$ & $0.0^{1}$ & $0.0^{\prime}$ \\
\hline & \multirow{4}{*}{$\begin{array}{l}\text { Manthar } \\
(5.05)\end{array}$} & $0 \mathrm{mg} / \mathrm{L}$ & $0.0^{1}$ & $0.0^{1}$ & $0.0^{1}$ & $0.0^{1}$ & $0.0^{\prime}$ \\
\hline & & $0.1 \mathrm{mg} / \mathrm{L}$ & $0.0^{\prime}$ & $8.25^{\mathrm{j}}$ & $17.75^{\mathrm{h}}$ & $43.50^{f}$ & $31.50^{g}$ \\
\hline & & $0.2 \mathrm{mg} / \mathrm{L}$ & $0.0^{1}$ & $0.0^{1}$ & $0.0^{1}$ & $0.0^{\prime}$ & $0.0^{1}$ \\
\hline & & $0.3 \mathrm{mg} / \mathrm{L}$ & $0.0^{1}$ & $0.0^{1}$ & $0.0^{\prime}$ & $0.0^{1}$ & $0.0^{1}$ \\
\hline
\end{tabular}


Table 4. Effect of different concentrations of Kinetin in combination with optimized concentrations of IAA and BAP (Table 2) on regeneration percentage. Letters indicate the comparison of different treatments.

\begin{tabular}{|c|c|c|c|c|c|c|}
\hline \multicolumn{7}{|c|}{ Kinetin } \\
\hline $\begin{array}{l}\text { Cultivars } \\
\text { (Genotypic } \\
\text { means) }\end{array}$ & & $0 \mathrm{mg} / \mathrm{L}$ & $0.1 \mathrm{mg} / \mathrm{L}$ & $0.2 \mathrm{mg} / \mathrm{L}$ & $0.3 \mathrm{mg} / \mathrm{L}$ & $0.4 \mathrm{mg} / \mathrm{L}$ \\
\hline \multirow{4}{*}{$\begin{array}{c}\text { Inqilab-91 } \\
\text { (18.788) }\end{array}$} & $0 \mathrm{mg} / \mathrm{L}$ & $0.0^{1}$ & $0.0^{1}$ & $0.0^{1}$ & $0.0^{1}$ & $0.0^{1}$ \\
\hline & BAP & $0.0^{1}$ & $0.0^{1}$ & $0.0^{1}$ & $13.0^{\mathrm{i}}$ & $41.25^{\mathrm{e}}$ \\
\hline & IAA & $0.0^{1}$ & $4.75^{\mathrm{jk}}$ & $15.00^{\mathrm{hi}}$ & $70.75^{b}$ & $80.25^{a}$ \\
\hline & IAA \& BAP & $72.00^{\mathrm{b}}$ & $45.75^{d}$ & $31.00^{f}$ & $2.00^{\mathrm{jkl}}$ & $0.0^{1}$ \\
\hline \multirow{4}{*}{$\begin{array}{c}\text { Chakwal-97 } \\
(13.413)\end{array}$} & $0 \mathrm{mg} / \mathrm{L}$ & $0.0^{1}$ & $0.0^{\prime}$ & $0.0^{1}$ & $0.0^{1}$ & $0.0^{1}$ \\
\hline & BAP & $0.0^{1}$ & $0.0^{1}$ & $0.0^{1}$ & $0.0^{1}$ & $11.75^{i}$ \\
\hline & IAA & $0.0^{\prime}$ & $4.00^{i}$ & $12.75^{i}$ & $69.50^{\mathrm{b}}$ & $73.00^{b}$ \\
\hline & IAA \& BAP & $70.00^{b}$ & $21.25^{\mathrm{g}}$ & $6.000^{g}$ & $0.0^{1}$ & $0.0^{1}$ \\
\hline \multirow{4}{*}{$\begin{array}{l}\text { Tatara } \\
(1.563)\end{array}$} & $0 \mathrm{mg} / \mathrm{L}$ & $0.0^{\prime}$ & $0.0^{1}$ & $0.0^{1}$ & $0.0^{\prime}$ & $0.0^{\prime}$ \\
\hline & BAP & $0.0^{1}$ & $0.0^{1}$ & $0.0^{1}$ & $0.0^{1}$ & $0.0^{\prime}$ \\
\hline & IAA & $0.0^{\prime}$ & $0.0^{1}$ & $1.00^{\mathrm{kl}}$ & $4.25^{\mathrm{jk}}$ & $12.00^{i}$ \\
\hline & IAA \& BAP & $12.25^{i}$ & $1.75^{\mathrm{kl}}$ & $0.0^{1}$ & $0.0^{1}$ & $0.0^{1}$ \\
\hline \multirow{4}{*}{$\begin{array}{l}\text { Manthar } \\
(9.463)\end{array}$} & $0 \mathrm{mg} / \mathrm{L}$ & $0.0^{1}$ & $0.0^{1}$ & $0.0^{1}$ & $0.0^{1}$ & $0.0^{1}$ \\
\hline & BAP & $0.0^{\prime}$ & $0.0^{1}$ & $0.0^{\prime}$ & $0.0^{\prime}$ & $0.0^{1}$ \\
\hline & IAA & $0.0^{1}$ & $13.75^{i}$ & $18.25^{\mathrm{gh}}$ & $33.75^{f}$ & $61.50^{c}$ \\
\hline & IAA \& BAP & $49.25^{d}$ & $12.00^{i}$ & $0.750^{i}$ & $0.0^{1}$ & $0.0^{1}$ \\
\hline
\end{tabular}


Table 5. Effect of different concentrations of 2iP in combination with optimized concentrations of IAA, BAP and Kinetin (Table 2 and Table 3) on regeneration percentage. Letters indicate the comparison of different treatments.

\begin{tabular}{|c|c|c|c|c|c|c|c|c|c|}
\hline \multirow{17}{*}{ 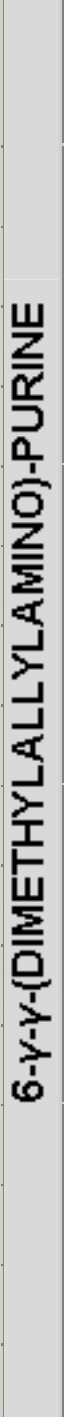 } & $\begin{array}{l}\text { Cultivars } \\
\text { (Genotypic } \\
\text { means) }\end{array}$ & & 0 & $\mathrm{Kn}$ & IAA & $\mathrm{IAA+Kn}$ & BAP & IAA+BAP & $\mathrm{BAP}+\mathrm{Kn}$ \\
\hline & \multirow{4}{*}{$\begin{array}{l}\text { Inqilab-91 } \\
(13.839)\end{array}$} & $0 \mathrm{mg} / \mathrm{L}$ & $0.0^{v}$ & $0.0^{v}$ & $0.0^{v}$ & $79.50^{c}$ & $0.0^{v}$ & $70.25^{\mathrm{e}}$ & $50.25^{i}$ \\
\hline & & $0.5 \mathrm{mg} / \mathrm{L}$ & $0.0^{v}$ & $2.75^{\text {qrstu }}$ & $0.0^{v}$ & $87.25^{\mathrm{a}}$ & $0.0^{v}$ & $3.750^{\mathrm{prqs}}$ & $0.0^{v}$ \\
\hline & & $1 \mathrm{mg} / \mathrm{L}$ & $0.0^{v}$ & $11.25^{\mathrm{mn}}$ & $54.75^{\mathrm{h}}$ & $19.00^{k}$ & $0.0^{v}$ & $0.0^{v}$ & $0.0^{v}$ \\
\hline & & $1.5 \mathrm{mg} / \mathrm{L}$ & $0.0^{v}$ & $12.50^{\mathrm{Im}}$ & $0.0^{v}$ & $0.0^{v}$ & $0.0^{v}$ & $0.0^{v}$ & $0.0^{v}$ \\
\hline & \multirow{4}{*}{$\begin{array}{c}\text { Chakwal-97 } \\
\text { (11.732) }\end{array}$} & $0 \mathrm{mg} / \mathrm{L}$ & $0.0^{v}$ & $0.0^{v}$ & $0.0^{v}$ & $75.50^{d}$ & $0.0^{v}$ & $64.50^{f}$ & $12.75^{\mathrm{Im}}$ \\
\hline & & $0.5 \mathrm{mg} / \mathrm{L}$ & $0.0^{v}$ & $5.50^{\mathrm{op}}$ & $0.0^{v}$ & $81.75^{\mathrm{b}}$ & $0.0^{v}$ & $3.000^{\mathrm{qrst}}$ & $0.0^{v}$ \\
\hline & & $1 \mathrm{mg} / \mathrm{L}$ & $0.0^{v}$ & $1075^{\mathrm{mn}}$ & $50.50^{i}$ & $13.50^{\prime}$ & $0.0^{v}$ & $0.0^{v}$ & $0.0^{v}$ \\
\hline & & $1.5 \mathrm{mg} / \mathrm{L}$ & $0.0^{v}$ & $10.75^{\mathrm{mn}}$ & $0.0^{v}$ & $0.0^{v}$ & $0.0^{v}$ & $0.0^{v}$ & $0.0^{v}$ \\
\hline & \multirow{4}{*}{$\begin{array}{l}\text { Tatara } \\
\mathbf{( 1 . 0 0 9 )}\end{array}$} & $0 \mathrm{mg} / \mathrm{L}$ & $0.0^{v}$ & $0.0^{v}$ & $0.0^{v}$ & $9.50^{n}$ & $0.0^{v}$ & $11.50^{I m n}$ & $0.0^{v}$ \\
\hline & & $0.5 \mathrm{mg} / \mathrm{L}$ & $0.0^{v}$ & $0.0^{v}$ & $0.0^{v}$ & $2.000^{\text {rstuv }}$ & $0.0^{v}$ & $0.0^{v}$ & $0.0^{v}$ \\
\hline & & $1 \mathrm{mg} / \mathrm{L}$ & $0.0^{v}$ & $1.75^{\text {stuv }}$ & $1.75^{\text {stuv }}$ & $0.75^{\mathrm{uv}}$ & $0.0^{v}$ & $0.0^{v}$ & $0.0^{v}$ \\
\hline & & $1.5 \mathrm{mg} / \mathrm{L}$ & $0.0^{v}$ & $1.000^{\text {tuv }}$ & $0.0^{v}$ & $0.0^{v}$ & $0.0^{v}$ & $0.0^{v}$ & $0.0^{v}$ \\
\hline & \multirow{4}{*}{$\begin{array}{l}\text { Manthar } \\
(7.563)\end{array}$} & $0 \mathrm{mg} / \mathrm{L}$ & $0.0^{v}$ & $0.0^{v}$ & $0.0^{v}$ & $61.50^{\mathrm{g}}$ & $0.0^{v}$ & $43.00^{j}$ & $0.0^{v}$ \\
\hline & & $0.5 \mathrm{mg} / \mathrm{L}$ & $0.0^{v}$ & $2.25^{\text {qrstu }}$ & $19.75^{k}$ & $68.75^{\mathrm{e}}$ & $0.0^{v}$ & $0.750^{\mathrm{uv}}$ & $0.0^{v}$ \\
\hline & & $1 \mathrm{mg} / \mathrm{L}$ & $0.0^{v}$ & $4.000^{p q r}$ & $0.0^{v}$ & $6.750^{\circ}$ & $0.0^{v}$ & $0.0^{v}$ & $0.0^{v}$ \\
\hline & & $1.5 \mathrm{mg} / \mathrm{L}$ & $0.0^{v}$ & $4.25^{\mathrm{pq}}$ & $0.0^{v}$ & $0.0^{v}$ & $0.0^{v}$ & $0.0^{v}$ & $0.0^{v}$ \\
\hline
\end{tabular}

